\title{
Intranidal temperature and body size of Africanized honey bees under heatwaves (Hymenoptera: Apidae)
}

\author{
Vianey Poot-BÁez ${ }^{1}$, Rubén Medina-Hernández ${ }^{1}$, Salvador Medina-Peralta ${ }^{2}$, \\ José Javier G. QuEZADA-EuÁN ${ }^{1}$
${ }^{1}$ Departamento de Apicultura Tropical, Campus de Ciencias Biológicas y Agropecuarias, Universidad Autónoma de Yucatán, Carretera Mérida-Xmatkuil, Mérida, México
${ }^{2}$ Facultad de Matemáticas, Campus de Ingenierías y Ciencias Exactas, Universidad Autónoma de Yucatán, Anillo \\ Periférico, Mérida, México
}

Received 15 July 2019 - Revised 17 October 2019 - Accepted 10 November 2019

\begin{abstract}
It is generally accepted that temperate subspecies of honey bees can maintain stable temperatures inside their nests; however, little information is available on the cooling ability of tropical honey bees and the effect of high environmental temperatures on individuals. In this study, we registered temperatures in the brood area of strong-and medium-populated colonies of Africanized honey bees during heatwaves (maximum environmental temperature 44 ${ }^{\circ} \mathrm{C}$ ) between April and May in the tropical Yucatán Peninsula of México. To evaluate the effect on colonies, we compared the body size of workers produced under high temperatures in the field and siblings produced at stable 34$35^{\circ} \mathrm{C}$ laboratory conditions. We found that in the field, temperatures of the brood nest in both types of colony can increase above $36^{\circ} \mathrm{C}$ during the hottest part of the day, especially in less strong colonies. Workers produced in the field were significantly smaller, compared to those reared in the lab at stable temperatures. This is a first study reporting body size reduction in honey bees as a consequence of possible thermoregulation disruption during heatwaves. We discuss our results considering potential effects of heat stress to Africanized honey bee colonies and tropical beekeeping.
\end{abstract}

thermal stress / climate change / tropical beekeeping / Yucatan Península / colony fitness

\section{INTRODUCTION}

Pollinators are increasingly under threat from human activities, including global warming. Several predictions state that the increase of the world's mean temperature by the end of the twenty-first century could be in the range of 0.3 ${ }^{\circ} \mathrm{C}$ to $4.8^{\circ} \mathrm{C}$ (IPCC 2014).

Electronic supplementary material The online version of this article (https://doi.org/10.1007/s13592-019-00725-5) contains supplementary material, which is available to authorized users.

Corresponding author: J. Quezada-Euán, javier.quezada@correo.uady.mx Handling editor: Klaus Hartfelder
The Western honey bee (Apis mellifera) is notable among insects because of the ability of effectively controlling brood temperatures within narrow variation of $34-36{ }^{\circ} \mathrm{C}$ (Kronenberg and Heller 1982; Ritter 1982,; Southwick 1987; Heinrich and Esch 1994). It is generally believed that compared with ectothermic aphids, honey bees can mitigate the negative impact of global warming due to the capacity of maintaining nest stable temperature by thermogenesis or cooling (Le Conte and Navajas 2008; IPBES 2016).

In general, honey bee nest thermoregulation has been more extensively studied in temperate environments, focusing more on aspects of nest heating rather than cooling it down (Bujok et al. 2002; Kleinhenz et al. 2003). The natural 
distribution of A. mellifera encompasses a wide variety of environments, including desertic, tropical, and temperate regions where multiple subspecies or "races" have evolved, showing contrasting differences in behavior and adaptation to their environments (Winston 1987; Ruttner 1988). Because of differential adaptation, subspecies contrast in their ability for temperature regulation and survival in temperate and hot environments (Abou-Shaara et al. 2017). For instance, it is known that tropical subspecies, like $A . m$. scutellata from Africa, exhibit reduced ability to survive at low temperatures and accordingly its natural southern distribution is limited to the 34 ${ }^{\circ} \mathrm{C}$ (Hepburn and Radloff 1998). Neotropical Africanized honey bees (AHB, a hybrid between A. $m$ scutellata and resident European honey bees, EHB) also exhibit latitude and altitude distribution limited by low temperatures (Sheppard et al. 1991; Quezada-Euán et al. 2003). Similarly, temperate subspecies have reduced adaptation and survival in hot climates (Abou-Shaara et al. 2017).

Few records of nest temperatures in honey bees have been made in the neotropics. In a preliminary study in Venezuela using one AHB and one European colony, it was found that nest temperatures in the hottest part of the year could reach above 39 ${ }^{\circ} \mathrm{C}$ in both (Villa et al. 1987). Moreover, how heat stress may affect honey bee colonies in tropical environments has been little investigated.

When nest overheats, workers engage in behaviors such as partial evacuation, in an attempt to reduce excess temperature (De Almeida 2008; Stabentheiner et al. 2010). This may leave immature stages (eggs, larvae, and pupae) unprotected from high temperatures for some periods, but the consequences have not been determined. Recently, it was found that AHB workers submitted to fluctuating high temperatures in the lab (maximum of $40{ }^{\circ} \mathrm{C}$ for $1 \mathrm{~h}$ ) during the pupal stage resulted in an early onset of foraging and a consequent shorter life span compared to siblings raised at $34-35^{\circ} \mathrm{C}$ (Medina et al. 2018).

The tropical Yucatan Peninsula of Mexico is among the top beekeeping areas in the world (Echazarreta et al. 1997). Indeed, the most productive beekeeping is practiced in the tropical and subtropical areas of Mexico where AHBs are predominant (Quezada-Euán 2007; Domínguez-
Ayala et al. 2016). Environmental temperatures in the Peninsula can reach up to $45^{\circ} \mathrm{C}$ during the dry season between April and June (Poot-Báez 2018). Understanding the effect of prolonged exposure to high temperatures is important for predicting the possible consequences of climate change on tropical honey bees and the livelihood of people who depend on apiculture in these regions (Oldroyd and Wongsiri 2006; Bradbear 2009; Moritz and Erler 2016; Switanek et al. 2017).

In this study, we recorded temperatures in the brood area of AHBs colonies under field conditions during heatwaves (April-May) and compared the body size of workers exposed to high environmental temperatures during the pupal stage with individuals from the same colonies maintained at stable temperatures in the lab. This type of investigation is basic for understanding the dynamics of nest thermoregulation in tropical bees and for planning strategies to mitigate the impact on imminent global warming on beekeeping in tropical regions.

\section{MATERIALS AND METHODS}

The study was conducted at Xmatkuil, $15.5 \mathrm{~km}$ south of Merida, Yucatan, Mexico, over a period of 3 months from March 2017 to May 2017, encompassing the dry and hottest season in the Yucatan. Environmental temperatures during this period can reach $42-43{ }^{\circ} \mathrm{C}$ for periods of a few hours per day and for several continuous days (Poot-Báez 2018).

Ten colonies kept in Langstroth hives were selected from commercial apiaries after being confirmed as Africanized. Colony origin was confirmed using the Fast Africanized Bee Identification System (FABIS), measuring the legs and wings of ten worker honey bees per colony (Rinderer et al. 1987). We selected colonies with mean FABIS probability of being Africanized of 0.99 .

The population of each colony was estimated using the surface area occupied by adult workers in accordance to the figures by Delaplane et al. (2013) and the classification as strong (80-100\% total surface of comb occupied), medium (60$79 \%$ of surface comb occupied), or weak (less 
than $60 \%$ of comb area occupied). We selected five medium populated (MP) colonies and five strong ones (SP). Temperature of the brood area in each colony was registered with the help of dataloggers (Extech® RHT10 and Sato® SKL200TH II $\alpha$ ). In each experimental colony, we placed one datalogger between the two central brood frames. The temperature of the brood area was registered continuously at $5 \mathrm{~min}$ intervals for $24 \mathrm{~h}$ three times per week during 3 weeks. An additional datalogger was placed in an empty hive in the same apiary to monitor environmental temperatures. Environmental temperatures in the shade were obtained from a local weather station too. The temperature between population strength (PS), colony, and PS-colony was compared using ANOVA for a two-factor factorial design in blocks (Montgomery 2013), followed by Tukey's multiple comparison test using STATGRAPHICS Centurion 18 (Statgraphics 2018) statistical software.

To evaluate the effect of extreme temperatures on the development of worker bees, we selected brood from the five MP colonies. We selected capped pupae (white pupae) after a heatwave between the 23rd and 28th of May. A comb section of ca. 70 cells was taken to the lab, while other section from the same comb (also ca 70 pupae) was also cut off but left in the hive during all the development of individuals. The comb sections in the lab were kept in wooden boxes at controlled conditions ( $34^{\circ}$ to $35.5^{\circ} \mathrm{C}$ and $75 \%$ humidity) in an environmental chamber (Binder KBF 720).

The comb sections were monitored to detect when worker bees started to emerge. Samples of emerging bees were collected from field and lab combs and kept in ethanol. Between 10 and 20 workers were dissected from each treatment colony. The right forewing, hind leg, head, and thorax were mounted on glass slides to be photographed using a Leica S8 APO microscope. Four morphometric variables associated with body size in bees were measured using ImageJ (Rasband 1997-2012) on each worker: head width, intertegular width, forewing length, and tibia length. A GLM procedure of the statistical software SPSS (2006) was used to compare the size of the different structures between treatments. Additionally, a principal component analysis
(PCA) was used to obtain parameters of overall body size combining the four morphometric traits measured on individual bees. PCA reduces the total variation of the data to a few variables called components. The correlation matrix procedure was selected as the resulting principal component1 (PC1) is better related with body size (Wiley 1981). The resulting coefficients for each PC were used to calculate scores as individual measures of body size. The individual scores of PC1 (related with body size) of field and lab workers were compared using the GLM procedure with treatment and colony and their interaction as the main factors.

\section{RESULTS}

The highest recording of environmental temperature in the empty hive was $44.3{ }^{\circ} \mathrm{C}$, during a heatwave between the $23 \mathrm{rd}$ and $28 \mathrm{th}$ of May. The average and maximum temperatures recorded in MP colonies during this period were $36.04( \pm$ $1.2)^{\circ} \mathrm{C}$ and $39.4( \pm 1.7){ }^{\circ} \mathrm{C}$. For the SP colonies, the average and maximum temperatures were 35.2 $( \pm 0.8){ }^{\circ} \mathrm{C}$ and $37.5( \pm 1.0){ }^{\circ} \mathrm{C}$, respectively (Figures 1 and 2). Average and maximum environmental temperatures in the shade were $32.5( \pm$ 4.7) ${ }^{\circ} \mathrm{C}$ and $39.7( \pm 4.4){ }^{\circ} \mathrm{C}$. The comparison of temperatures between MP and SP colonies was statistically significant $\left(\mathrm{F}_{1,1296(0.01)}=926.95\right.$; Supplementary file 1). The ANOVA also revealed an effect of colony $\left(\mathrm{F}_{4,1296(0.01)}=66.82, \mathrm{P}<\right.$ $0.001)$ and the interaction between population strength and colony $\left(\mathrm{F}_{4,1296(0.01)}=125.09, \mathrm{P}<\right.$ 0.001). Notably, recordings of nest temperatures in the nests of MP colonies during the heatwave reached $40{ }^{\circ} \mathrm{C}$ but only for $1 \mathrm{~h}$ in average (between 15 and $16 \mathrm{~h}$ ), a value much higher than those considered safe for brood development (Figure 2). In comparison, temperatures in highly populated ones in the same period of time were also above the $35^{\circ} \mathrm{C}$ but did not go over $39^{\circ} \mathrm{C}$ (Figure 2). In general, nest temperatures fluctuated more in MP colonies compared with SP ones (Figure 2). During the highest temperatures, we observed nest evacuation of adult population more frequently and in more numbers in SP colonies compared with MP ones. 

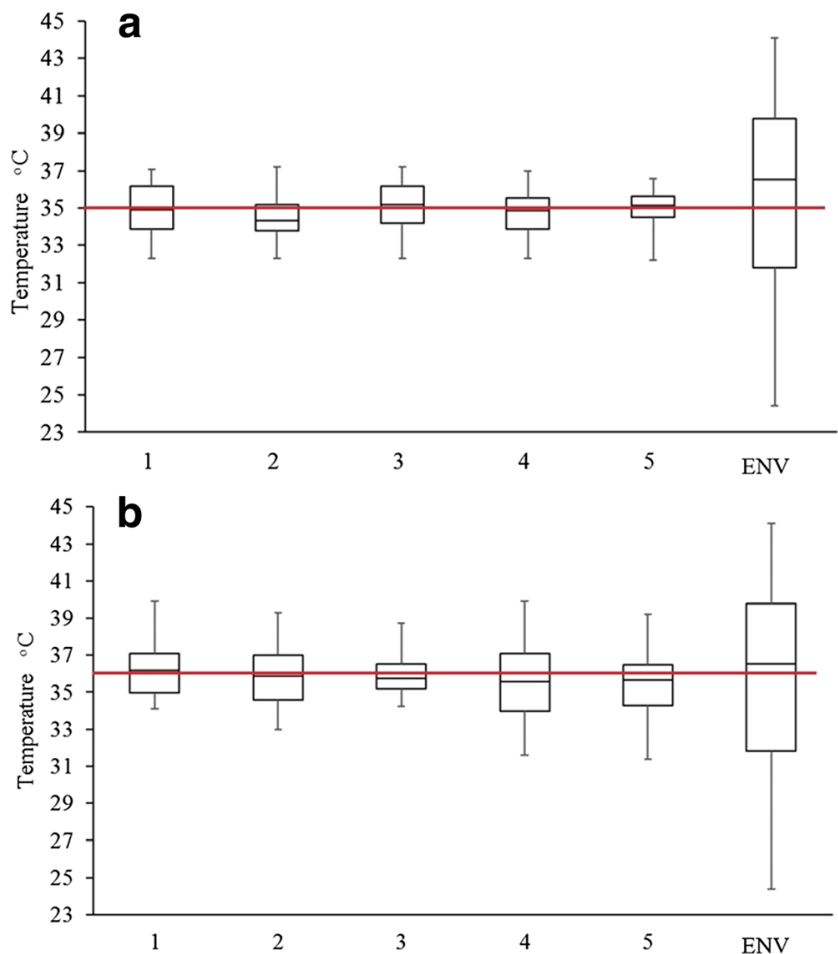

Figure 1. Average mean temperatures per colony (numbered 1 to 5) for the week between 23rd and 28th of May 2018 during a heatwave in SP (A) and MP (B) groups, together with environmental (ENV) temperatures. The ends of each box are the upper and lower quartiles; the whiskers represent the average of the highest and lowest temperatures. The red line represents the average temperature of the colonies in each group.

Regarding the body size of workers reared under heatwave conditions in the field and stable conditions in the lab, it was found that the former were significantly smaller in all four traits measured (Table I, Supplementary file 2). We used the PC1 and PC2 coefficients (Supplementary file 3) to calculate individual scores. The mean of scores for PC1 was significantly smaller in field bees (Figure 3; Supplementary file 2). It is generally accepted that PC1 reflects body size (Wiley 1981) and, thus, the values of scores of field bees for that component confirm their overall smaller body size (Table I; Figure 3). In addition to the effect of treatment, colony also had a significant effect on intertegular distance $\left(\mathrm{F}_{4,165}(0.01)=6.62\right)$, forewing length $\left(\mathrm{F}_{4,165(0.01)}=29.4\right)$, and tibia length $\left(\mathrm{F}_{4,165}\right.$ $(0.01)=13.8)$. Likewise, there was a significant effect of colony on PC1 $\left(\mathrm{F}_{4,165}(0.01)=17.7\right)$. The interactions between colony and treatment were significant only for forewing $\left(\mathrm{F}_{4,165}(0.01)=\right.$ 11.32) and tibia length $\left(\mathrm{F}_{4,165(0.01)}=5.02\right)$.

\section{DISCUSSION}

We found that during heatwaves, the nest temperature of colonies of AHBs can significantly increase above those considered normal for development of individuals in temperate regions. Notably, the nest temperature of MP colonies increased significantly more compared with SP ones. It was also found that pupae exposed to high environmental temperatures in the field (12-13 days) resulted in smaller workers compared with those reared in the lab, under conditions considered stable for development.

Our results provide evidence that social buffering of honey bee colonies in tropical conditions may be challenged during heatwaves. However, 


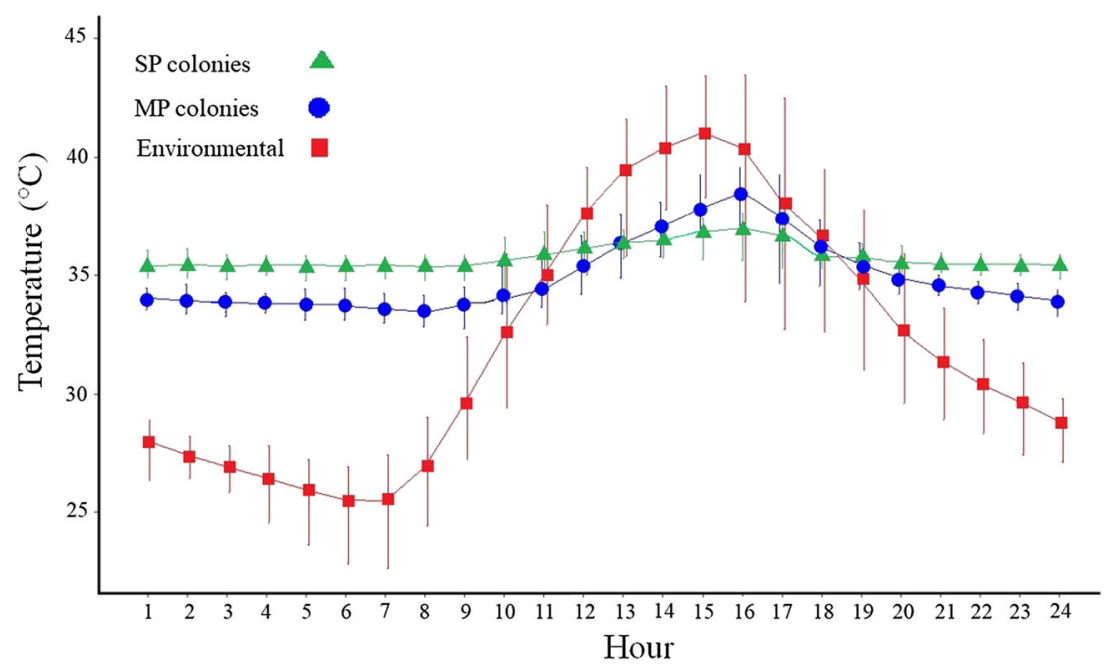

Figure 2. Average mean temperatures per hour in both groups SP (A) and MP (B ) of colonies for the week between 23rd and 28th of May 2018 during a heatwave, together with environmental temperatures. The whiskers represent the average of the highest and lowest temperatures.

the temperature of the nests increased only in the hottest hours of the day, particularly in MP colonies, returning to those considered normal after. AHB workers kept in shaded hives were able to maintain their body temperatures at relatively normal levels, but this ability is hindered at environmental temperatures above $36^{\circ} \mathrm{C}$ causing almost linear increases of body temperature (Domingos et al. 2018). Thus, thermoregulation mechanisms can be disrupted above certain environmental temperature (in our study ca. $43^{\circ} \mathrm{C}$ ) causing the colonies to keep pace with rising outdoor temperatures. Probably to compensate temperature increase during the hottest part of the day, colonies evacuated the hive, and this was more frequent in SP colonies, presumably leaving immature stages exposed to high temperatures. However, contrary to expectations, the temperature of the brood in SP colonies was significantly more stable during these hours compared with MP ones. In general, the temperature of MP colonies varied more than the SP ones. Therefore, SP colonies seem to better thermoregulate the brood under heatwaves. Heat-dissipating mechanisms may be performed more efficiently in colonies with numerous workers. In colonies exposed to heat stress, workers collect and deposit water on combs and cells, while

Table I.. Comparison of means for morphometric characters and scores for principal components (PC1 and PC2) of AHB workers reared under controlled temperature conditions (lab) and in the field exposed to heat stress (field). $* *$ denotes significant at $\mathrm{P}<0.01$; NS denotes not significant at $\mathrm{P}<0.01$.

Treatment

\begin{tabular}{llllll}
\hline Character & \multicolumn{2}{c}{ Lab $(n=50)$} & \multicolumn{2}{c}{ Field $(n=91)$} & $F$ value \\
& Mean & St err & Mean & St err & \\
Head width $(\mathrm{mm})$ & $3.681 \mathrm{a}$ & 0.012 & $3.602 \mathrm{~b}$ & 0.006 & $26.8^{* *}$ \\
Intertegular distance $(\mathrm{mm})$ & $2.777 \mathrm{a}$ & 0.015 & $2.730 \mathrm{~b}$ & 0.008 & $8.03^{* *}$ \\
Forewing length $(\mathrm{mm})$ & $8.600 \mathrm{a}$ & 0.028 & $8.239 \mathrm{~b}$ & 0.015 & $128.3^{* *}$ \\
Tibia length $(\mathrm{mm})$ & $2.697 \mathrm{a}$ & 0.015 & $2.569 \mathrm{~b}$ & 0.008 & $59.04^{* *}$ \\
PC1 & $0.769 \mathrm{a}$ & 0.138 & $-0.307 \mathrm{~b}$ & 0.077 & $82.64^{* *}$ \\
PC2 & $0.099 \mathrm{a}$ & 0.159 & $-0.248 \mathrm{~b}$ & 0.088 & $6.17 \mathrm{NS}$ \\
\hline
\end{tabular}




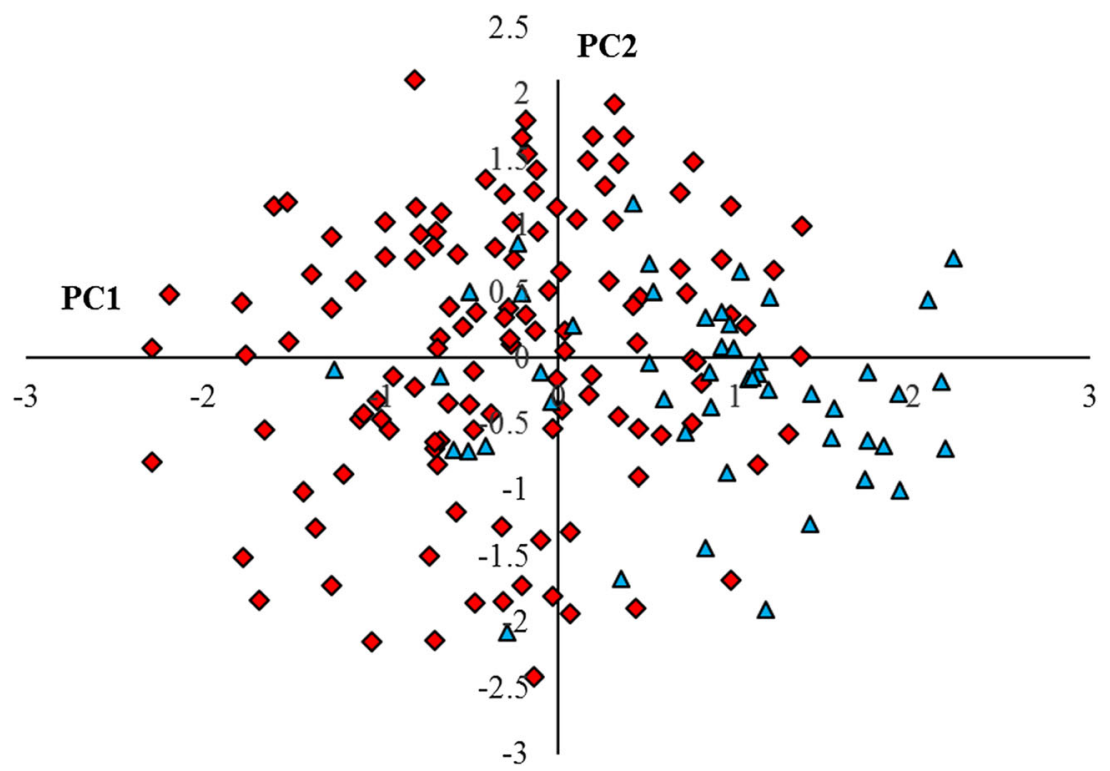

Figure 3. Distribution of principal components 1 and 2 (PC1 and PC2) score values of AHB workers reared at stable temperature in the lab (blue triangles) and under heat stress in the field (red triangles).

others create air currents by fanning their wings to eliminate heat by water evaporation and convection (Jones and Oldroyd 2007). In addition, although part of the population empty the nest to reduce the heat produced by metabolism, some workers remain inside acting as shields against excessive heat (Siegel et al. 2005). Shield workers move more intensely to the hottest area in the hive, to create air currents and dissipate heat and/or to absorb it and move it to less heated areas in the nest (Siegel et al. 2005). Notably, the initiation and thresholds of thermoregulatory behavior seem to depend on the population of colonies (Starks and Gilley 1999; Cook and Breed 2013; Cook et al. 2016). In addition, nest cooling requires that different workers engage in several activities at the same time (Egley and Breed 2012). Therefore, colonies with strong populations could engage faster and more efficiently in nest cooling because of the large number of workers available. Weak colonies, on the contrary, may assign less numbers of individuals to each of the different mechanisms to reduce nest overheating or they may concentrate in only a few of these, resulting in less efficient thermoregulation of the nest.

High environmental temperatures during worker development can affect several traits of the resulting individuals, from physical and behavioral abnormalities to death in extreme cases. In contrast with adults, honey bee brood is stenothermic, and accurate temperature regulation is needed for proper development. The pupae are even more sensitive to temperature changes compared with earlier stages (Stabentheiner et al. 2010). Nest temperature can affect the rate of development of individuals. In temperate honey bees, slow development occurs when temperatures reduce below normal (Fukuda and Sakagami 1968) and presumably accelerates when nest temperatures rise. In ectotherms, a general increase of physiological processes occurs at higher temperature resulting in fast developing individuals and smaller body size (Chown et al. 2002). An accelerated metabolism and consequent faster development of the larvae in overheated nests may explain why workers under field conditions were smaller than those reared at constant temperatures in the lab. To our knowledge, this is the first time that high temperatures in the field are linked to body reduction in honey bees, as these are generally regarded as efficient thermoregulators.

The reduction in size of the different measured traits in field bees was less than 5\% compared with those reared under lab conditions. It would be 
adventurous to predict the effect of such magnitude of reduction in body size of individual workers on colony fitness and productivity. However, it is known that several components of worker body size are important for colony fitness. Pupal weight, corbicular size, and proboscis length have been correlated honey production in temperate honey bees (Milne Jr. 1980; Milne Jr. and Pries 1984). In AHBs, honey production is also influenced by pupal weight (Souza et al. 2002; Zárate et al. 2008) and significantly correlated with the corbicular area (Souza et al. 2002). Indeed, smaller bees may have limited capacity to carry large or heavy loads (Milne Jr. and Pries 1986), reducing the opportunity of colonies to accumulate large reserves which in turn may compromise colony reproduction and survival, as well as productivity.

Important traits other than body size may also be affected in AHB workers reared under heat stress. In temperate honey bees, the transition from in-hive to outdoor activities, longevity, and communication can be altered in workers that develop at abnormal high temperatures (Tautz et al. 2003; Jones et al. 2005; Becher et al. 2010; Abou-Shaara et al. 2017). Similarly, AHB pupae reared at fluctuating high temperatures in the lab showed higher rates of body asymmetry and an early start of foraging coupled with shorter life span (Medina et al. 2018).

Although potential negative effects may be associated with nest overheating in individual AHBs workers such as shorter life span (Medina et al. 2018), and in our study body size, more evidence is needed to understand of the ultimate effects on colony fitness and productivity. Indeed, the adaptation of different subspecies to their historic climate conditions is well-documented (Villa et al. 1987; Abou-Shaara et al. 2012; Kovac et al. 2014; Alattal and Alghamdi 2015; Abou-Shaara et al. 2017), and it may be possible that AHB colonies could better stand increases in environmental temperatures with less negative effects compared with EHB. It should also be considered that AHBs in tropical and subtropical conditions may exhibit several adaptations over their temperate counterparts, such as disease resistance (Martin and Medina 2004) and active foraging at high temperatures (Heinrich 1979). Nonetheless, measures should be taken to protect hives from extreme heat. Colonies kept in shade potentially invest less energy in thermoregulation compared with those kept in direct sun light, which may result in differential productivity (Domingos et al. 2018).

Our results indicate that AHBs colonies exposed to high environmental temperatures can experience an increase in nest temperature and workers could become smaller as a result. Notably, strong colonies can better control those increments. Recommendations to ameliorate possible negative effects should be directed to maintain colonies with strong populations and to provide them with adequate shade and nearby water during the hottest months of the year. In addition to the risks of disease transmission and genetic erosion, introduction of stocks from temperate areas does not seem a plausible strategy for tropical beekeeping under the eminent effects of global warming. We think a better option for tropical and subtropical Mexico would be to select/ reproduce honey bees already adapted to local conditions and take advantage of their tolerance to heat.

\section{ACKNOWLEDGMENTS}

We thank CONACYT projects 237532 "Cambio Climático y polinizadores" and 291333 "Manejo sustentable de polinizadores" for supporting this investigation and for student grants to VPB and RMH. We are very thankful to two anonymous reviewers and the editor for their comments and corrections that greatly improved our ms.

Température à l'intérieur du nid et taille corporelle des abeilles africanisées lors des vagues de chaleur (Hymenoptera : Apidae).

Stress thermique / changement climatique / apiculture tropicale / péninsule du Yucatan / bonne santé de la colonie.

Temperatur innerhalb des Nests und Körpergröße von afrikanisierten Honigbienen bei Hitzewellen (Hymenoptera: Apidae).

Thermischer Stress / Klimawandel / Bienenhaltung in den Tropen / Yucatan-Halbinsel / Fitness des Bienenvolks. 


\section{REFERENCES}

Abou-Shaara, H.F., Al-Ghamdi, A.A., Mohamed, A.A. (2012) Tolerance of two honey bee races to various temperature and relative humidity gradients. Env. Exp. Biol. 10,133-138.

Abou-Shaara, H.F., Oways, A.A., Ibrahim, Y.Y., Basuny, N.K., (2017) A review of impacts of temperature and relative humidity on various activities of honey bees. Insectes Soc. 64, 455-463. https://doi.org/10.1007 /s00040-017-0573-8.

Alattal, Y., Alghamdi, A. (2015) Impact of temperature extremes on survival of indigenous and exotic honey bee subspecies, Apis mellifera, under desert and semiarid climates. Bull. Insectol. 68, 219-222.

Becher, M.A., Hildenbrandt, H., Hemelrijk, C. K., Moritz, R.F.A. (2010) Brood temperature, task division and colony survival in honeybees: a model. Ecological Modelling. 221, 769-776.

Bradbear, N. (2009) Bees and their role in forest livelihoods: A guide to the services provided by bees and the sustainable harvesting, processing and marketing of their products. FAO, Rome, $192 \mathrm{pp}$.

Bujok, B., Kleinhenz, M., Fuchs, S., Tautz, J. (2002) Hot spots in the bee hive. Naturwissenschaften 89, 299-301.

Chown, S.L., Addo-Bediako, A., Gaston, K.J. (2002) Physiological variation in insects: large-scale patterns and their implications. Comp. Biochem. Physiol. B 131, 587-602.

Cook, C. N., Breed, M. D. (2013) Social context influences the initiation and threshold of thermoregulatory behaviour in honeybees. Animal Behav. 86, 323-326.

Cook, C. N., Kaspar, R. E., Flaxman, S. M., Breed, M. D. (2016) Rapidly changing environment modulates the thermoregulatory fanning response in honeybee groups. Animal Behav. 115, 237-243.

De Almeida, G. F. (2008) Fatores que interferem no comportamento enxameatório de abelhas africanizadas. Doctoral dissertation, Tese Doutorado em Ciências-Faculdade de Filosofia, Ciências e Letras de Ribeirão Preto, Universidade de São Paulo, Ribeirão Preto.

Delaplane, K. S., van der Steen, J., Guzman-Novoa, E. (2013) Standard methods for estimating strength parameters of Apis mellifera colonies. J. Apic. Res. 52 (1), 1-12.

Domingos, H.G.T., Sombra, D.S., Santos, R.G., Gramacho, K.P., Gonçalves, L.S. (2018) Surface temperature and heat transfer between body regions of Africanized honeybees (Apis mellifera L.) in hives under sun and shade conditions in the northeastern semi-arid region of Brazil. J. Agric. Sci. Tech. A 8, 28-35.

Domínguez-Ayala, R., Moo-Valle, H., May-Itzá, W. de J., Medina-Peralta, S., Quezada-Euán, J. J. G. (2016) Stock composition of northern neotropical honey bees: mitotype and morphotype diversity in México (Hymenoptera: Apidae). Apidologie 47, 642-652.
Echazarreta, C. M., Quezada-Euán, J. J. G., Medina, M. L., Pasteur, K. L. (1997) Beekeeping in the Yucatán peninsula: development and current status. Bee World $\mathbf{7 8}$, 115-127.

Egley, R.L., Breed, M. D. (2012) The fanner honey bee: behavioral variability and environmental cues in workers performing a specialized task. J. Insect Behav. 26, 238-245

Fukuda, H., Sakagami, S.F. (1968) Worker brood survival in honeybees. Res. Pop. Ecol . 10, 31-39.

Heinrich, B. (1979) Thermoregulation of African and European honeybees during foraging, attack, and hive exits and returns. J. Exp. Biol. 80, 217-229.

Heinrich, B., Esch, H., 1994 Thermoregulation in bees. Am. Sci. 82, 164-170. https://doi.org/10.2307/29775151.

Hepburn, H.R., Radloff, S.E. (1998) Honeybees of Africa. Springer-Verlag Berlin 369 pp.

IPBES (2016) The assessment report of the Intergovernmental Science-Policy Platform on Biodiversity and Ecosystem Services on pollinators, pollination and food production. S.G. Potts, V. L. Imperatriz-Fonseca, and H. T. Ngo, (eds). Secretariat of the Intergovernmental Science-Policy Platform on Biodiversity and Ecosystem Services, Bonn, Germany. 552 pages

IPCC (2014) Cambio climático 2014: Informe de síntesis. Contribución de los Grupos de trabajo I, II y III al Quinto Informe de Evaluación del Grupo Intergubernamental de Expertos sobre el Cambio Climático [Equipo principal de redacción, R.K. Pachauri \& L.A. Meyer (eds.)]. IPCC, Ginebra, Suiza, 157 pp

Jones, J. C., Oldroyd, B. P. (2007) Nest thermoregulation in social insects. Advances in insect Physiology 33, 153191.

Jones, J.C., Helliwell, P., Beekman, M., Maleszka, R., Oldroyd, B.P. (2005) The effects of rearing temperature on developmental stability and learning and memory in the honey bee, Apis mellifera. J. Comp. Physiol. A $191,1121-1129$.

Kleinhenz, M., Bujok, B., Fuchs, S., Tautz, J. (2003) Hot bees in empty brood nest cells: heating from within. J. Exp. Biol. 206, 4217-4231.

Kovac, H., Käfer, H., Stabentheiner, A., Costa, C. (2014) Metabolism and upper thermal limits of Apis mellifera carnica and A. m. ligustica. Apidologie 45,664-677.

Kronenberg, F., Heller, H. C. (1982) Colonial thermoregulation in honey bees (Apis mellifera). J. Comp. Physiol. B, 148 (1), 65-76.

Le Conte, Y., Navajas, M. (2008) Climate change: impact on honey bee populations and diseases. Revue Scientifique et Technique-Office International des Epizooties, 27, 499-510.

Martin, S.J., Medina, L.M. (2004) Africanized honeybees have unique tolerance to Varroa mites. Trends in Parasitology $20,112-114$.

Medina, R. G., Paxton, R. J., De Luna, E., Fleites-Ayil, F. A., Medina, L. A. M., Quezada-Euán, J. J. G. (2018) Developmental stability, age at onset of foraging and longevity of Africanized honeybees (Apis mellifera L .) 
under heat stress (Hymenoptera: Apidae). J. Therm. Biol. 74, 214-225. https://doi.org/10.1016/j. jtherbio.2018.04.003

Milne, C.P. Jr. (1980) Laboratory measurement of honey production in the honey bee. 3. Pupal weight of the worker. J. Apic. Res. 19, 176-178.

Milne, C.P. Jr., Pries, K.J. (1984) Honey bee corbicular size and honey production. J. Apic. Res. 23, 11-14.

Milne, C.P. Jr., Pries, K.J. (1986) Honeybees with larger corbiculae carry larger pollen pellets. J. Apic. Res. 25, $53-54$.

Montgomery, D.C. (2013) Design and Analysis of Experiments. 8th Edition, Wiley \& Sons, New Jersey, USA.

Moritz, R. F. A., Erler, S. (2016) Lost colonies found in a data mine: global honey trade but not pests or pesticides as a major cause of regional honeybee colony declines. Agriculture, Ecosystems \& Environment 216, 44-50.

Oldroyd, B.P., Wongsiri, S. (2006) Asian honey bees, biology, conservation and human interactions. Harvard Univ. Press, 339 pp.

Poot-Báez, V.E. (2018) Efecto de la fluctuación de temperatura en el tamaño de obreras de Apis mellifera en épocas de calor en Yucatán, México. Bachelor dissertation. Universidad Autónoma de Yucatán, Yucatán, México.

Quezada-Euán, J.J.G. (2007) A retrospective history of the expansion of Africanized honeybees in Mexico. J. Apic. Res. \& Bee World 46, 295-300.

Quezada-Euán, J.J.G., Pérez-Castro, E.E., May-Itzá, W. d. J. (2003) Hybridization between European and African-derived honeybee populations (Apis mellifera) at different altitudes in Perú. Apidologie 34, 217-225.

Rasband, W.S. (1997-2012) ImageJ, U.S. National Institutes of Health, Bethesda, Maryland, USA, imagej.nih. gov/ij/

Rinderer, T.E., Sylvester, H.A., Buco, S.M., Lancaster, V.A., Herbert, E.W., Collins, A.M., Hellmich II, R.L. (1987) Improved simple techniques for identifying Africanized and European honey bees. Apidologie 18, 179-196. https://doi.org/10.1051 /apido:19870208.

Ritter, W. (1982) Experimenteller Beitrag zur Thermoregulation des Bienenvolkes (Apis mellifera L.). Apidologie 13, 169-195.

Ruttner, F. (1988) Biogeography and taxonomy of honeybees. Springer Verlag, New York 284 pp.

Sheppard, W.S., Soares, A.E.E., DeJong, D., Shimanuki, H. (1991) Hybrid status of honey bee populations near the historic origin of Africanization in Brazil. Apidologie 22, 643-652.
Siegel, A.J., Hui, J., Johnson, R.N., Starks, P.T. (2005) Honey bee workers as mobile insulating units. Insect. Soc. 52, 242-246.

Southwick, E.E. (1987) Cooperative metabolism in honey bees: An alternative to antifreeze and hibernation. J. Thermal Biology 12, 155-158.

Souza, D.C., Cruz, C.D., Oliveira Campos, L.A., Regazzi, A.J. (2002) Correlation between honey production and some morphological traits in Africanized honey bees (Apis melifera ). Ciência Rural, Santa Maria, 32 (5), 869-872.

SPSS, Inc (2006) SPSS for Windows version 15. SPSS, Inc, Chicago.

Stabentheiner, A., Kovac, H., Brodschneider, R. (2010) Honeybee colony thermoregulation - regulatory mechanisms and contribution of individuals in dependence on age, location and thermal stress. PLOS ONE 5(1), e8967. doi:https://doi.org/10.1371/journal. pone.0008967.

Starks, P.T., Gilley, D.C. (1999) Heat shielding: a novel method of colonial thermoregulation in honey bees. Naturwissenschaften 86, 438-440.

Statgraphics Technologies, Inc. (2018). STATGRAPHICS Centurion 18 Version 18.1.06.

Switanek, M., Crailsheim, K., Truhetz, H., Brodschneider, R. (2017) Modelling seasonal effects of temperature and precipitation on honey bee winter mortality in a temperate climate. Sci. Total Environ. 579, 15811587. https://doi.org/10.1016/j.scitotenv.2016.11.178.

Tautz, J., Maier, S., Groh, C., Roessler, W., Brockmann, A. (2003) Behavioral performance in adult honey bees is influenced by the temperature experienced during their pupal development. Proc. Nat. Acad. Sci. USA $100,7343-7347$.

Villa, J.D., Gentry, C., Taylor, O.R. (1987) Preliminary observations on thermoregulation, clustering, and energy utilization in African and European honey bees. J. Kans. Entomol. Soc . 60, 4-14.

Wiley, E.O. (1981) Phylogenetics, the theory and practice of Phylogenetic systematics. John Wiley \& Sons NY,439 pp.

Winston, M.L. (1987) The Biology of the Honey Bee. Harvard Univ. Press. Cambridge, Mass. 281 pp.

Zárate, O., Araujo-Freitas, C., Medina, L.A., Velásquez, A., Quezada-Euán, J.J.G. (2008) Phenotypic correlations of field and laboratory tests with honey production in Africanized honey bees (Apis mellifera). Apidologie 39, 523-530.

Publisher's note Springer Nature remains neutral with regard to jurisdictional claims in published maps and institutional affiliations. 